\title{
The possible significance of IgA in abnormal cerebrospinal fluid
}

\author{
NEELA K. SHETH \\ From the Department of Haematology, St George's Hospital, London
}

SYNOPSIS In a study of 21 patients with disease of the central nervous system $\operatorname{IgA}$, which is normally absent, could be detected in the cerebrospinal fluid in the presence of meningitis of bacterial or fungal origin: the concentration of $\operatorname{IgA}$ in the cerebrospinal fluid could not, however, be correlated with serum levels. A reaction of non-identity has been demonstrated between serum and cerebrospinal fluid $\operatorname{IgA}$ using the diffusion technique on cellulose acetate.

These data seem to suggest that cerebrospinal fluid IgA is produced independently of serum IgA and can be detected in measurable amounts where microorganisms are the cause of inflammatory disease of the central nervous system.

Immunoglobulin levels in the cerebrospinal fluid in disease states have been studied on only a few occasions and definite patterns have not yet been established. The purpose of this study was to determine IgG and IgA levels in normal and abnormal cerebrospinal fluids and to compare these with serum IgG and IgA levels. An attempt has been made to determine whether the cerebrospinal fluid IgA is identical with serum IgA.

\section{Materials and Methods}

Sera and cerebrospinal fluids from 21 patients with disease of the central nervous system were chosen. Bloodstained specimens were excluded from this study. Fluids from five patients suspected of having Received for publication 24 August 1970. involvement of the central nervous system but found to be normal were chosen as controls.

The total protein content of all cerebrospinal fluids was estimated by a turbidimetric method using $3 \%$ sulphosalicylic acid.

Immunoelectrophoresis on agar gel was performed by the micro-method of Scheidegger (1955). Cerebrospinal fluids were used neat and after tenfold concentration. Those showing detectable amounts of IgG and $\operatorname{IgA}$ were investigated further.

IgG and IgA levels were then measured using three standards for each IgG and IgA. The immunoplates (Hyland) containing anti-IgG were incubated for four hours at $37^{\circ} \mathrm{C}$ and those containing anti-IgA for 16 hours at room temperature; the diameters of the precipitin rings were then measured. Using a two-cycle semilogarithmic graph paper, standard

\begin{tabular}{|c|c|c|c|c|c|c|c|}
\hline \multirow[t]{2}{*}{ No. } & \multirow[t]{2}{*}{ Patient } & \multirow[t]{2}{*}{ Clinical Diagnosis } & \multirow{2}{*}{$\begin{array}{l}\text { Total Protein } \\
\text { in C.S.F. }\end{array}$} & \multicolumn{2}{|c|}{ Immunoglobulin $G^{1}$} & \multicolumn{2}{|c|}{ Immunoglobulin $A^{1}$} \\
\hline & & & & Serum & $C S F$ & Serum & $C S F$ \\
\hline 1 & F.F. & Normal & 25 & 1,500 & $3 \cdot 8$ & 350 & $\mathbf{0}$ \\
\hline 2 & C.D. & Normal & 45 & 1,100 & $3 \cdot 5$ & 320 & $\mathbf{0}$ \\
\hline 3 & C.A. & Normal & 35 & 1,500 & $3 \cdot 0$ & 280 & $\mathbf{0}$ \\
\hline 4 & H.M. & Cerebral aneurysm & 25 & 1,800 & $2 \cdot 0$ & 400 & $\mathbf{0}$ \\
\hline 5 & M.V. & Spinal block? Secondary carcinomatosis & 1,500 & 1,850 & $30 \cdot 0$ & 400 & $\mathbf{0}$ \\
\hline 6 & I.B. & Glioma & 10 & 1,780 & $2 \cdot 2$ & 150 & $\mathbf{0}$ \\
\hline 7 & H.G. & Glioma & 135 & 1,200 & $\overline{7} \cdot \overline{0}$ & 300 & $\mathbf{0}$ \\
\hline 8 & P.D. & Glioma & 180 & 1,400 & $15 \cdot 5$ & 280 & $\mathbf{0}$ \\
\hline 9 & V.R. & Glioma & 105 & 1,800 & $31 \cdot 0$ & 400 & $\mathbf{0}$ \\
\hline 10 & R.D. & Glioma & 50 & 1,300 & $7 \cdot 0$ & 270 & $\mathbf{0}$ \\
\hline 11 & S.F. & Glioma, postoperative reactive meningitis & 40 & 1,200 & $10 \cdot 0$ & 200 & $\mathbf{0}$ \\
\hline 12 & M.G. & Postoperative reactive meningitis & 80 & 1,500 & $4 \cdot 0$ & 250 & $\mathbf{0}$ \\
\hline
\end{tabular}

Table I Results in cerebrospinal fluids from normal and abnormal cases 


\begin{tabular}{|c|c|c|c|c|c|c|c|}
\hline \multirow[t]{2}{*}{ No. } & \multirow[t]{2}{*}{ Patient } & \multirow[t]{2}{*}{ Clinical Diagnosis } & \multirow{2}{*}{$\begin{array}{l}\text { Total Protein } \\
\text { in CSF }\end{array}$} & \multicolumn{2}{|c|}{ Immunoglobulin $G^{1}$} & \multicolumn{2}{|c|}{ Immunoglobulin $A^{1}$} \\
\hline & & & & Serum & $C S F$ & Serum & $C S F$ \\
\hline 1 & L.T. & Bacterial meningitis & 50 & 1,850 & $7 \cdot 5$ & 600 & $3 \cdot 5$ \\
\hline 2 & L.M. & Glioma with meningitis & 200 & 1,500 & $18 \cdot 5$ & 200 & $4 \cdot 2$ \\
\hline 3 & M.B. & Chronic bacterial meningitis & 100 & 2,750 & $19 \cdot 0$ & 700 & $17 \cdot \overline{5}$ \\
\hline 4 & M.M. & Postoperative bacterial meningitis & 115 & 1,850 & $10 \cdot 0$ & 400 & $5 \cdot 5$ \\
\hline 5 & R.G.S. & Cryptococcal abscess & 130 & 2,750 & 26.0 & 360 & $5 \cdot 5$ \\
\hline \multirow[t]{2}{*}{6} & L.C. & Spinal haemangioblastoma with secondary & & & & & \\
\hline & & bacterial meningitis & 70 & 1,800 & $24 \cdot 0$ & 300 & $10 \cdot 2$ \\
\hline 7 & A.S. & Cerebral glioma? Secondary infection & 400 & 1,700 & $17 \cdot 0$ & 320 & 6.5 \\
\hline 8 & J.G. & Bacterial meningitis & 90 & 1,500 & $8 \cdot 0$ & 400 & $2 \cdot 8$ \\
\hline 9 & H.S. & Bacterial meningitis & 50 & 1,100 & $2 \cdot 0$ & 200 & $2 \cdot 0$ \\
\hline
\end{tabular}

Table II Results in abnormal cerebospinal fluids

${ }^{1}$ Results in $\mathrm{mg} / 100 \mathrm{ml}$.

lines were plotted, using the concentrations of the standard sera on the ordinate log scale. The values of the test specimens are expressed as milligrams per $100 \mathrm{ml}$.

The diffusion technique on cellulose acetate was used to demonstrate the reaction of non-identity or identity between cerebrospinal fluid and serum IgA. Goat serum prepared against human IgA (Hyland) was used as the specific antibody.

\section{Results}

The total protein content of abnormal cerebrospinal fluids ranged from $10 \mathrm{mg}$ to $400 \mathrm{mg}$ per $100 \mathrm{ml}$, except for one exceptionally high value of $1,50 \dot{\theta}$ $\mathrm{mg} / 100 \mathrm{ml}$.

Immunoelectrophoresis on agar gel showed that normal and abnormal cerebrospinal fluids contained detectable amounts of IgG.

IgA was not detected in normal cerebrospina fluids used neat and after tenfold concentration, but was detectable in some of the abnormal fluids These were then separated for further study together with the corresponding sera (Tables I and II). Igष and IgA levels in these fluids and sera were measure by the methods previously described.

Figure 1 shows the cerebrospinal fluid IgG values plotted against serum IgG, and Figure 2 show

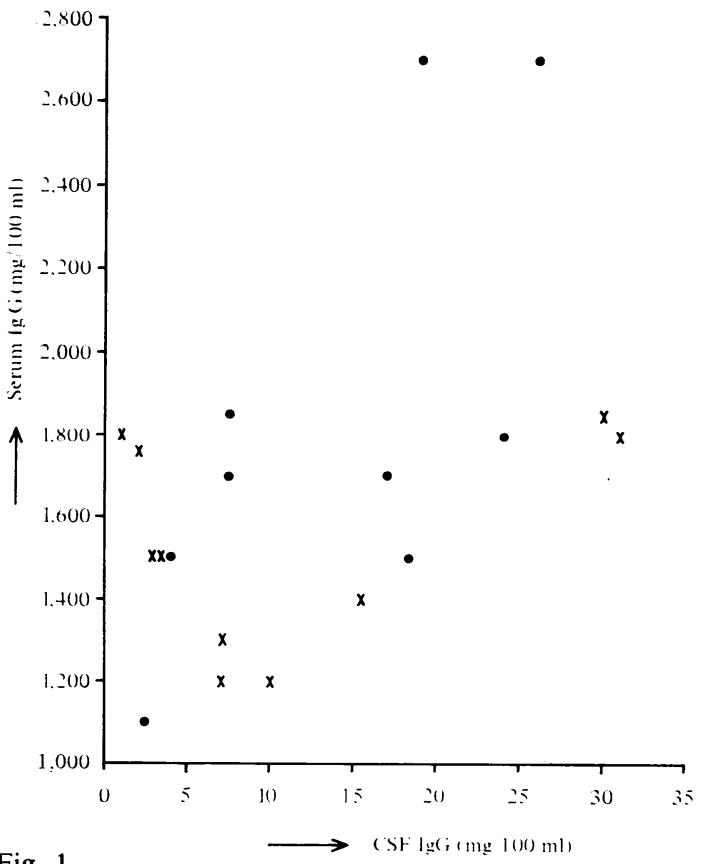

Fig. 1

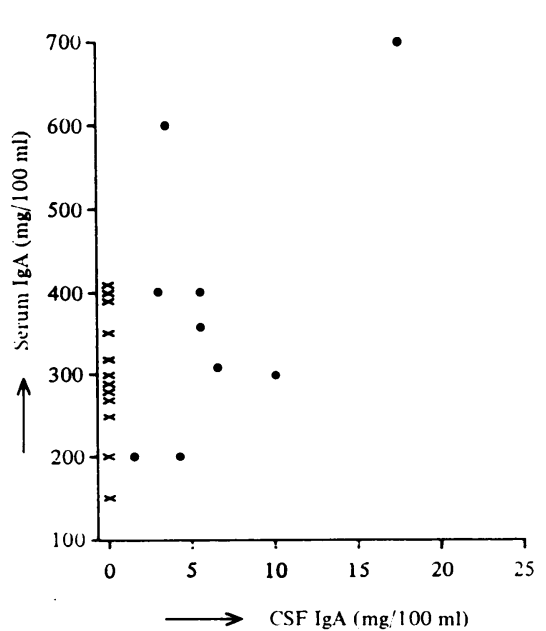

Fig. 2.

Fig. $1 \mathrm{X}=$ Normal, tumours, etcetera; $=$ meningitis $\stackrel{\mathbb{D}}{\Omega}$

Fig. $2 \mathrm{X}=$ Normal, tumours, etcetera; $=$ meningitis 
cerebrospinal fluid IgA and the corresponding serum IgA values.

\section{Discussion}

\section{CEREBR OSPINAL IgG}

In the few normal cases studied, IgG was demonstrable in cerebrospinal fluid in amounts ranging up to $4 \mathrm{mg} / 100 \mathrm{ml}$ but IgM was not detectable.

Hartley, Merrill, and Clanman (1966), studying patients with neurological disorders, could not find any correlation between serum and cerebrospinal fluid IgG. In the abnormal cerebrospinal fluids in the present series, there was no consistent relationship between the rise in IgG and any particular disease, the increase differing in a variety of conditions involving the central nervous system, irrespective of the level of total proteins in the cerebrospinal fluid and independently of changes in the serum.

\section{CEREBROSPINAL IgA}

IgA levels cannot be detected in normal cerebrospinal fluid by currently available techniques, but in the abnormal fluids studied IgA was found in cases of chronic meningitis due either to bacteria or fungi. All those containing IgA had a raised total protein (Fig. 3). This finding has also been noted by Riddoch and Thompson (1970) in their series of 207 patients, which included five cases of inflammatory disease. Their experience, however, cannot be compared with the present study in which cases chosen were only of neurosurgical interest. IgA could not be found in cases of reactive meningitis following aseptic operative procedures or in patients with aneurysm or cerebral neoplasm.

As with IgG, there appears to be no correlation

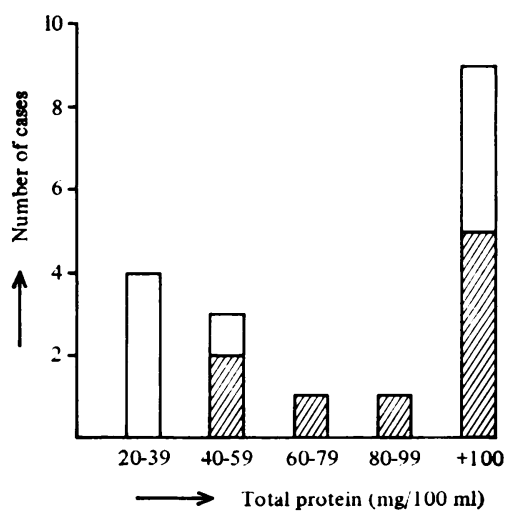

Fig. 3 Hatched areas show number of cases with raised $\operatorname{IgA}$. between serum and cerebrospinal fluid IgA levels. Frick and Scheid-Seydel (1958), using ${ }^{131}$ I tagged gamma globulin intravenously, found that an equilibrium between serum and cerebrospinal fluid gamma globulin levels could be established within 100 hours in normal fluid using normal gamma globulins. But equilibrium could not be established in cases where the gamma globulin level in cerebrospinal fluid was already raised, possibly because the gamma globulin present in inflammatory states may be of local origin.

The lack of correlation between serum and cerebrospinal fluid levels of IgA in the present study may indicate that the two do not equilibrate even in the presence of longstanding disease. A local origin for IgA in cerebrospinal fluid has been suggested on this basis. The reactions of non-identity between serum and cerebrospinal fluid $\operatorname{IgA}$ suggest that there is an immunochemical difference, but there is the outside possibility that these may be due to other protein contaminants giving non-specific precipitation lines, especially as concentrated cerebrospinal fluids were used (Tomasi and Bienenstock, 1968).

Detailed antigenic identification is beyond the scope of this paper. Kolar, Russell, and Hartlage (1970) have recently noted a difference in the immunoelectrophoretic appearance in serum and cerebrospinal fluid IgA.

Cerebrospinal fluid IgA in chronic inflammatory disease of the meninges may be of independent origin and not a so-called 'pathotopic potentiation' from extravasation of antibody from serum in inflammatory disease. Its detection may help to decide whether a cellular reaction in the cerebrospinal fluid is merely a postoperative or mechanical response, or is due to the presence of microorganisms.

I wish to thank Professor J. L. Stafford for his support and helpful suggestions, and $\mathrm{Dr} M$. R. Crompton for the histopathological diagnosis of the cases studied.

\footnotetext{
References

Frıck, E., and Scheid-Seydel, L. (1958). Untersuchungen mit J $\mathrm{J}^{131}$ markiertem $\gamma$-globulin zur Frage der Abstammung der Liquoreiweisskörper. Klin. Wschr., 36, 857-863.

Hartley, T. F., Merrill, D. A., and Claman, H. F. (1966). Quantitation of immunoglobulins in cerebrospinal fluid. Arch. Neurol. (Chic.), 15, 472-479.

Kolar, O., Russell, D., and Hartlage, P. (1970). IgD and IgA in cerebrospinal fluid. Lancet, 1, 622-623.

Riddoch, D., and Thompson, R. A. (1970). Immunoglobulin levels in the cerebrospinal fluid. Brit. med. J., 1, 396-399.

Scheidegger, J. J. (1955). Une micro-méthode de l'immuno-électrophorèse. Int. Arch. Allergy, 7, 103-110.

Tomasi, T. B. Jr., and Bienenstock, J. (1968). Advances in Immunology, Vol. 9, pp. 1-96. Academic Press, New York.
} 